УДК 621.311

\title{
ДО ОПТИМАЛЬНОГО КОМБІНУВАННЯ ВІТРОВИХ ТА СОНЯЧНИХ ЕЛЕКТРОСТАНЦЙ
}

\author{
М.П. Кузнєцов ${ }^{1}$, докт. техн. наук, О.В. Лисенко ${ }^{2}$, канд. техн. наук, О.А. Мельник ${ }^{3}$, аспірант. \\ ${ }^{1}$ Інститут відновлюваної енергетики НАН України \\ 02094 вул. Гната Хоткевича, 20А, м. Київ \\ ${ }^{2}$ Таврійський державний агротехнологічний університет \\ 72310 м. Мелітополь, пр-т Б. Хмельницького, 18. \\ ${ }^{3}$ Національний технічний університет України «Київський політехнічний інститут ім. Ігоря Сікорського», \\ 03056, м. Київ, пр-т Перемоги 37.
}

\begin{abstract}
Метою даної роботи є визначення оптимального співвідномення різних джерел відновлюваної енергї в гібридних енергосистемах, базуючись на оиінках випадкової складової потужностей генерації та споживання електроенергії. Для иьього розглядаються короткотермінові коливання потужності, спричинені природними змінами сонячної та вітрової енергії в діапазоні менше години. Такі зміни впливають на можливості регулювання частоти й напруги, а також стійкості систем електропостачання. Предметом дослідження є пропориія вітрової та сонячної генерачії, а також ї̈ загальний рівень у споживанні електроенергії, а предметом оптимізації - варіативність сукупної генерованої потужності. Особливістю роботи є синхронне співставленні рівнів генерації енергії та їі споживання різними локальними споживачами. Методи дослідження - математична модель комбіначії випадкових прочесів та безпосереднє використання статистичних даних в якості експериментальних. Методом оптимізаиії обрано побудову поверхні відгуку, щъо забезпечує візуалізацію результатів при задовільній точності. При необхідності результат уточнюється методом дихотомії. Результати дослідження порівнюються за рівнем впливу погодних факторів, для чого розглядаються дані різних пір року. Отримані залежсності дозволяють також оцінити вплив енергетичної ефективності вітрової та сонячної енергетики як технологічного фактору. Істотним результатом є оцінка впливу точності прогнозування потужностей генерації і споживання на енергетичний баланс при складанні графіків роботи енергосистеми - так, наявність добового прогнозу дозволяє в півтора рази збільшити потужність ВДЕ при збереженні рівня варіативності. Встановлено наявність оптимальних співвідношень потужності ВЕС та СЕС, при яких мінімізується загальна варіативність енергобалансу. В умовах України ие складає приблизно третину номінальної потужності ВДЕ за рахунок ВЕС та дві третини СЕС, однак результати суттєво залежать від сезону. Запропоновано критерії оптимальності, щъо враховують випадкову природу досліджуваних процесів, ие дає можливість імовірнісної оцінки результатів. Бібл. 13, рис. 6.
\end{abstract}

Ключові слова: відновлювані джерела енергї, сонячна електростанція, вітрова електростаниія, енергобаланс, випадковий процес, оптимізаиія.

\section{TO OPTIMAL COMBINATION OF WIND AND SOLAR ELECTRICITY}

\author{
M. Kuznietsov, doctor of technical science, O. Lysenko, candidate of technical science, A. Melnyk, graduate student.
}

${ }^{1}$ Institute of renewable energy, NAS of Ukraine, 02094, 20A Hnata Khotkevycha St., Kyiv.

${ }^{2}$ Tavria State Agrotechnological University,

72310, 18 B.Khmelnitskoho Avenue, Melitopol.

${ }^{3}$ National Technical University of Ukraine "Igor Sikorsky Kiev Polytechnic Institute",

03056, 37 Peremohy Av., Kyiv.

The purpose of the paper is to determine the optimal ratio of different sources of renewable energy in hybrid power systems, based on the estimation of the random component of power generation and electricity consumption. For this purpose short-term power fluctuations caused by natural changes in solar and wind energy in the time frame of less than an hour are considered. Such changes affect the performance of frequency and voltage regulation, as well as the stability of power supply systems. The subject of the study is the proportion of wind and solar generation with its overall level of electricity consumption and the point of optimization - the variability of the total generated power. The key feature of the work is the synchronous alignment of the levels of energy generation and consumption by different local consumers. Methods of research are a mathematical model of a combination of random processes and the direct use of experimental statistical data. The chosen method of optimization is the construction of the response surface, which provides the visualization of the results with satisfactory accuracy. If necessary, the result is specified by the method of dichotomy. The outputs of the study are compared with different weather factors, so the data of the different seasons were examines. The obtained dependencies also allow to estimate the influence of energy efficiency of wind and solar power engineering as a technological factor. Among the important results is when drawing up the schedules of the power system it is possible to estimate the influence of the prediction accuracy of generation and consumption capacities on the energy balance: the presence of a daily forecast allows to increase the power of RES in 1.5 times, while maintaining the level of variability. The existence of optimal ratios of the WPP and PV power with the minimum general variability of the energy balance is established. In Ukraine it is about one third of the rated power of the wind power and two thirds of the $P V$, but the results are significantly dependent on the season. The optimality criteria are considered, taking into account the random nature of the investigated processes, which gives the possibility of probabilistic estimation of the results. References 13, fig. 6.

Keywords: renewable energy sources, solar power station, wind power plant, energy balance, random process, optimization. 


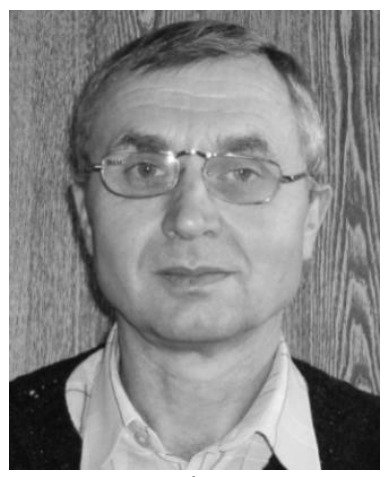

М. П. Кузнецзов M. Kuznietsov

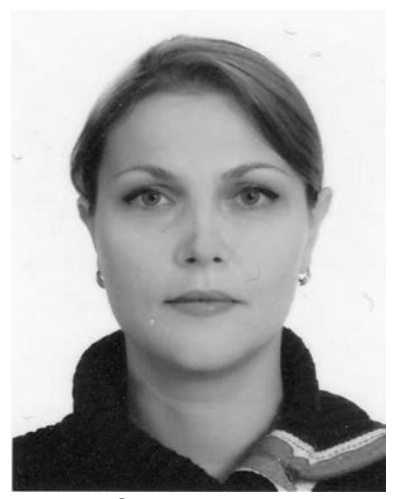

О. В. Лисенко

O. Lysenko

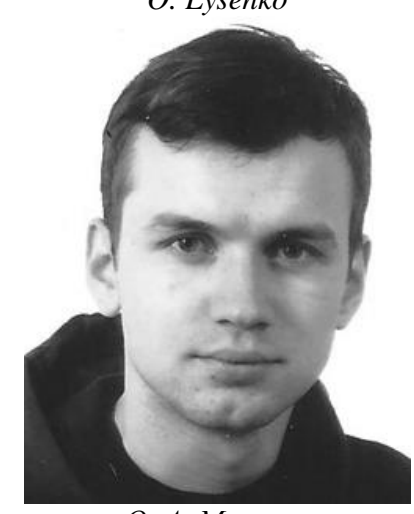

О. А. Мельник

O. Melnyk
Відомості про автора: заступник директора Інституту відновлюваної енергетики НАН України, старший науковий співробітник, доктор технічних наук.

Освіта: Київський державний університет ім. Т. Шевченка, механіко-математичний факультет.

Наукова сфера: математика, відновлювана енергетика.

Публікації: понад 60, у тому числі 3 монографіï.

ORCID: 0000-0002-0497-7439

Контакти: тел./факс: +38 (044) 206-28-09 e-mail: renewable@ukr.net

Відомості про автора: доцент кафедри енергетики та автоматизації Таврійського державного агротехнологічного університету, доцент, кандидат технічних наук. Освіта: Таврійська державна агротехнічна академія, енергетичний факультет.

Наукова сфера: електропостачання, відновлювана енергетика.

Публікації: понад 40, у тому числі 4 патенти.

ORCID: 0000-0001-7085-7796

Контакти: тел.: +38 (061) 942-06-18

факс: +38 (061) 942-24-11

e-mail: office@tsatu.edu.ua

Відомості про автора: аспірант, інженердослідник.

Освіта: Національний технічний університет України «Київський політехнічний інститут ім.І.Сікорського», факультет електроенерготехніки та автоматики.

Область наукових інтересів: електроенерготехніка, відновлювана енергетика. Публікації: 6.

ORCID: 0000-0003-2894-3476

Контакти: тел./факс: +38(044) 236-21-49 e-mail: aspirantura@kpi.ua
Author information: Deputy Director of the Institute of Renewable Energy at the NASU, Doctor of technical sciences.

Education: Taras Shevchenko Kyiv State

University, Faculty of Mechanics and

Mathematics.

Research area: mathematics, renewable energy.

Publications: over 60, including 3

monographs.

ORCID: 0000-0002-0497-7439

Conatacts: tel./fax: +38 (044) 206-28-09

e-mail: renewable@ukr.net

Author information: Associate Professor, Department of Energy and Automation Tavria State Agrotechnological University, Associate Professor, Candidate of Technical Sciences.

Education: Tavria State Agrotechnical Academy, Energy.

Research area: power supply, renewable energy.

Publications: over 40, including 4 patents ORCID: 0000-0001-7085-7796

Contacts: tel.: $+38(061)$ 942-06-18

fax: +38 (061) 942-24-11

e-mail: office@tsatu.edu.ua

Author information: graduate student, research engineer.

Education: National Technical University of Ukraine "Igor Sikorsky Kyiv Polytechnic Institute", Faculty of Electric Power Engineering and Automatics.

Main research interests: electric power engineering, renewable energy.

Publications: 6.

ORCID: 0000-0003-2894-3476

Contacts: тел./факс: +38(044) 236-21-49

e-mail: aspirantura@kpi.ua

Перелік використаних позначень та скорочень:

ВДЕ - відновлювані джерела енергії;

ВЕС - вітрова електростанція;

СЕС - сонячна електростанція;

$K_{\text {ввп }}-$ коефіцієнт використання встановленої потужності;

$P\{x\}$ - імовірність події $x$;

$\sigma$ - середньоквадратичне відхилення (СКВ);

$w$ - потужність ВЕС (в.о.);

$s-$ потужність СЕС (в.о);

$C_{v}$ - коефіцієнт варіації;

$R$ - абсолютна потужність ВДЕ (кВТ);

$r$ - відносна потужність ВДЕ (в.о.).
Вступ. Змінний і слабо прогнозований в короткостроковій перспективі характер видачі потужності, властивий вітровій та сонячній енергетиці, може привести до негативного впливу на режими роботи енергосистеми. Це, зокрема, стосується стійкості динамічних процесів в системах електропостачання та відповідно організації диспетчерського управління енергосистемами. Крім того, збільшення частки вітрових (BEC) і соняч- них (СЕС) електростанцій в енергосистемі буде витісняти традиційні електростанції, що ускладнить можливість регулювання частоти. Таким чином, має бути достатньо резерву для регулювання частоти і забезпечення надійного електропостачання в разі втрати генерації або навантаження, що особливо важливо для недостатньо гнучких енергосистем зі значним рівнем впровадження вітрової та сонячної енергетики. 
Серед інших проблем важливими і актуальними можна вважати: неоптимальні режими роботи мережі, пов'язані зі стохастичним характером генерації [2]; можливість появи зворотного потоку потужності в електричній мережі, оскільки сучасні ВЕС, як і СЕС, підключаються до розподільних мереж через інвертори, які зазвичай спроектовані для роботи в певних межах напруги і частоти; при небалансі потужності може відбутись відключення від мережі і втрата «зеленої» енергії навіть при сприятливих погодних умовах;

Як бачимо, більшість проблем пов'язано 3 нерівномірним режимом генерації на основі відновлюваних джерел енергії (ВДЕ). Поєднання різнотипних джерел енергії здатне знизити гостроту проблеми, вирівнявши режим генерації i зменшивши випадкову складову.

Постановка задачі. Вирішенню проблеми оптимізації комбінованих систем електропостачання присвячено ряд робіт українських та зарубіжних вчених. Зокрема, це питання вибору відновлюваних потужностей на основі оцінки їх впливу на балансову надійність [1]. В роботі [2] розглядаються методи моделювання та оптимізації автономних комбінованих систем електропостачання на основі аналізу їх технікоекономічних показників. Робота [3] присвячена аналізу сучасних методів оптимізації, призначених для малих і автономних енергосистем. Відзначено, що вдале математичне моделювання здатне забезпечити оптимізацію системи без значного обсягу метеорологічних даних. Сучасною тенденцією є також управління як генерацією енергії, так і ії споживанням [4]. Огляд методів і моделей комбінованих систем електропостачання 3 точки зору мінімуму приведених витрат наведено в роботі [5]. Крім оптимізації за технічними показниками, опублікований ряд робіт, присвячених економічній оптимізації комбінованих електричних систем на основі ВДЕ [6], яке дозволяє також задовольнити технічні та екологічні обмеження.

Природна вимога при побудові комбінованої енергосистеми на базі відновлюваних джерел (ВДЕ) - мінімізація неконтрольованого розкиду значень генерованої потужності при максимізації виробленої енергії. В економічній постановці задачі оптимізації роль і вага середньої потужності ВДЕ та середньоквадратичного відхилення (СКВ) різна, вона визначається вартістю електроенергії і засобів

Відновлювана енергетика. 2019. № 1

резервування та/чи акумулювання, але кращий результат забезпечує наявність обох критеріїв.

Потреба оцінювати саме випадкову складову коливань потужності слідує з різних причин [7]. Значне впровадження ВДЕ, якщо воно не супроводжується достатнім акумулюванням енергії, потребуватиме балансування поточних коливань генерованої енергії. Буде потрібен достатній обсяг резерву для регулювання частоти та забезпечення надійного постачання у випадку швидкої зміни генерації чи навантаження. Баланс споживання електроенергії та регулювання частоти основні технічні проблеми при значному рівні впровадження вітрової та сонячної енергетики [8]. При цьому зміна частоти в мережі пропорційна зміні регулюючої потужності (залежно від крутизни статичної частотної характеристики), що визначає допустиму зміну потужності (див. напр. «Основні вимоги щодо регулювання частоти та потужності в ОЕС України. Настанова» СОУ-Н ЯЕК 04.156:2009). Коливання напруги також пов'язані з небалансом генерації та споживання електроенергії. Це ж стосується і стійкості енергосистеми. Так, відповідно до СОУ-Н МЕВ 40.1.00100227-68:2012 «Стійкість енергосистеми. Керівні вказівки» вплив перепадів потужності на стійкість визначається за таким показником, як коефіцієнт запасу стійкості з активної потужності в контрольованому перетині (вузлі) електромережі, величина якого розраховується в залежності від амплітуди нерегулярних коливань активної потужності; саме розмах нерегулярних змін $є$ визначальним при розрахунку запасу стійкості. Як свідчить аналіз статистичних даних, робота ВЕС і СЕС характеризується наявністю деякої середньої потужності та випадкової складової, що є функціями часу. Середня потужність може вважатися добре прогнозованою на короткотривалу перспективу, і вважатися контрольованим параметром [9]. Тоді обмеження мають бути накладені саме на випадкову складову балансу потужностей, яка й визначає величину запасу стійкості.

Методи і алгоритми розв'язку. Розглянемо спочатку сумісну роботу вітрової та сонячної станцій незалежно від способу споживання їх енергії (умовно на необмеженого споживача). Використаємо статистичні дані про погодні фактори, характерні для умов півдня України [10], та врахуємо нормовані показники потужності ВЕС та CEC. Отже, позначимо: $w$ - відносна частка номінальної потужності ВЕС, а $s$ - відповідно 
$\mathrm{CEC}$, при цьому прийнято: $w+s=1$. Тоді значення $w=1$ відповідає наявності лише ВЕС у складі блоку відновлюваної енергетики (ВДЕ), а $w=0$ - наявності лише СЕС.

Середньорічні показники генерованої потужності $\left(P_{\mathrm{c}}\right)$ та середньоквадратичного відхилення (CКВ) сумарної генерації ВЕС та СЕС при різних комбінаціях їх поєднання зображено на рис.1. Крім потужності та відхилень зображено їх пропорцію коефіцієнт варіації: $C_{v}=\frac{\sigma}{P_{c}}$, де $\sigma-\mathrm{CКВ.}$

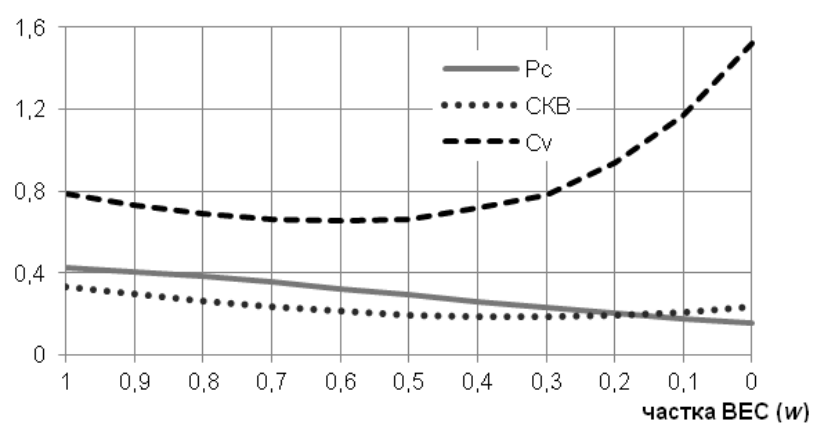

Рис. 1. Сумарна потужність ВЕС та СЕС (відносні величини)

Fig. 1. Total power of WPP and PV (relative values)

Використання встановленої потужності для вітроустановок традиційно вище порівняно з фотомодулями (це особливості їх технологій та клімату). Тому при зменшенні частки ВЕС середня потужність ВДЕ в даному прикладі падає внаслідок меншого загального коефіцієнту використання встановленої потужності $\left(K_{\text {ввп }}\right)$, а показники мінливості мають нелінійний характер. При врахуванні повної доби мінімальне СКВ середньорічних значень досягається при частці ВЕС на рівні 0,32 загальної потужності ВДЕ, а мінімум коефіцієнта варіації $C_{v}$ відповідає частці $w=0,56$. Якщо враховувати лише робочі години (8.00-18.00), то мінімум по СКВ - коли частка вітру рівна 0,33 (практично без мін); по $C_{v}-0,38$ (бо середня розрахункова потужність СЕС вища). Отже, якщо за критерій брати лише коефіцієнт варіації потужності як комбінований показник відхилень та середньої потужності, то мінімум досягається при частці ВЕС 0,56 від сумарної потужності ВДЕ.

На рис.1 зображено сумарну мінливість власне ВДЕ (вітрової та сонячної енергії). Однак на практиці важливою $є$ стабільність постачання енергії з урахуванням мінливої природи її споживання. Розглянемо сумісні коливання рівнів генерування електричної енергії від ВДЕ та іiї спожи- вання різними споживачами (приклади споживання наведено в $[10,11])$. При цьому вважаємо, що традиційна генерація забезпечує певний, передбачений заздалегідь, графік постачання енергії, а імовірні поточні відхилення від графіка складають небаланс потужності і відповідно енергії.

Рівень поточного споживання електроенергії звичайно має певні відхилення (флуктуації) відносно осередненого графіка. Їх розкид визначає потребу в компенсуючих потужностях (резервних чи акумулюючих), якщо осереднений графік споживання вважати плановим. Наявність ВДЕ 3 випадковим графіком генерації впливає на загальну варіативність потреб у традиційному постачанні енергії, оскільки випадковим чином змінює небаланс потужності. Поточне споживання за вирахуванням надходжень від ВДЕ іменують «чистим» навантаженням (net base load) в термінології [12]. Порівняємо розкид випадкових відхилень від осередненого графіка споживання для різних споживачів при варіюванні потужностями BEC та CEC (вважається, що графік навантаження складено з урахуванням осередненого добового ходу ВДЕ).

Спочатку припускаємо, що прогнозування рівнів споживання та генерації не передбачено, $\mathrm{i}$ осереднення (тобто графік чистого навантаження) виконано по місячному масиву ретроспективних даних. При цьому потужності ВДЕ визначено як проектні за результатами попередніх досліджень. Сумарна номінальна потужність ВДЕ розраховується для різних рівнів впровадження, співмірних 3 потужністю споживання. Предметом оптимізації є варіативність навантаження (абсолютна та відносна) залежно від частки ВДЕ та пропорції «ВЕС/СЕС».

Формула побудови місячного набору даних про баланс генерації та споживання електроенергії, відповідно до припущення про плановий графік, має вигляд:

$$
p_{i j}=\left(a_{i j}-a_{i}\right)-\left[\left(w_{i j}-w_{i}\right)+\left(s_{s j}-s_{i}\right)\right],
$$

де $a_{x}$ - рівень споживання електроенергії; $w_{x}$ та $s_{x}$ - потужність ВЕС та СЕС відповідно; $i$ - індекс часу (в даних прикладах крок 30 хв.); $j$ - номер доби. Тут $p_{i j}$ - відхилення від графіка навантаження. Показники ВДЕ з одним індексом - осереднені на певну годину дня (добовий хід), зокрема $a_{i}$ має відповідати плановому графіку споживання. Тоді $p_{i}=a_{i}-w_{i}-s_{i}$ відповідає плановому «чистому» навантаженню. 
Перехід від встановленої (тобто номінальної) до середньої робочої (або ефективної) потужності можливий за допомогою коефіцієнта викорис-

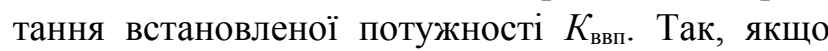
сумарна номінальна потужність ВДЕ рівна $R$ (Renewable), а ефективна $-r$ (relative), то

$$
r=R\left(k_{w} w+k_{s} s\right)=R\left[k_{w} w+k_{s}(1-w)\right],
$$

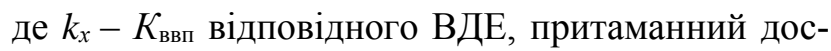
ліджуваному регіону та порі року. Тоді розв'язками задачі оптимізації будуть $\operatorname{argmax}_{\mathbf{R}, w} \boldsymbol{r}$ та $\operatorname{argmin}_{R, w} \boldsymbol{D}\left\{\boldsymbol{p}_{i, j}\right\}$ (двокритеріальна задача) при умові виконання відповідних обмежень, де символом $D=\sigma^{2}$ позначено дисперсію. Пріоритетність критеріїв визначатиметься залежно від потреб і залежатиме головним чином від вартісних показників традиційної й відновлюваної енергії та засобів забезпечення енергобалансу.

В якості комбінованого одиничного критерію може виступати коефіцієнт варіації $C_{V}=\sigma / r$ як відношення СКВ до математичного очікування (а не номінального значення, як на рис.1); його мінімум $\epsilon$ результатом як зростання ефективної потужності ВДЕ, так і зменшення варіативності.

Якщо визначати відносну варіативність як відношення додаткового СКВ до відповідної робочої потужності ВДЕ, характер залежності дещо зміниться (рис. 3б), хоча оптимальні пропорції збережуться. Так, при зростанні частки ВДЕ в загальній генерації СКВ навантаження зростає прискорено, а відносна варіація $\left(C_{V r}\right)$ - сповільнено.

Для коефіцієнта додаткової варіації прийнято:

$$
C_{V}=\left(\sigma_{R}-\sigma_{0}\right) / R, C_{V r}=\left(\sigma_{R}-\sigma_{0}\right) / r
$$

де індекс «R» стосується енергосистеми з ВДЕ, а $« 0 »-$ без ВДЕ.

Результати. Виконаємо дослідження роботи енергосистем з різним рівнем впровадження ВЕС та СЕС при споживанні електроенергії, характерному для певних категорій споживачів. На рис. 23 зображено приклади результатів моделювання небалансу потужності для споживача типу невеликого населеного пункту при різних рівнях впровадження ВДЕ. Використано фактичні дані щодо споживання електроенергії та погодних факторів, а потужність ВДЕ змодельована для відповідних енергетичних характеристик. Для пошуку екстремуму в першому наближенні застосовано метод «поверхні відгуку» (response surface), а уточнення - методом дихотомії (dividing search).

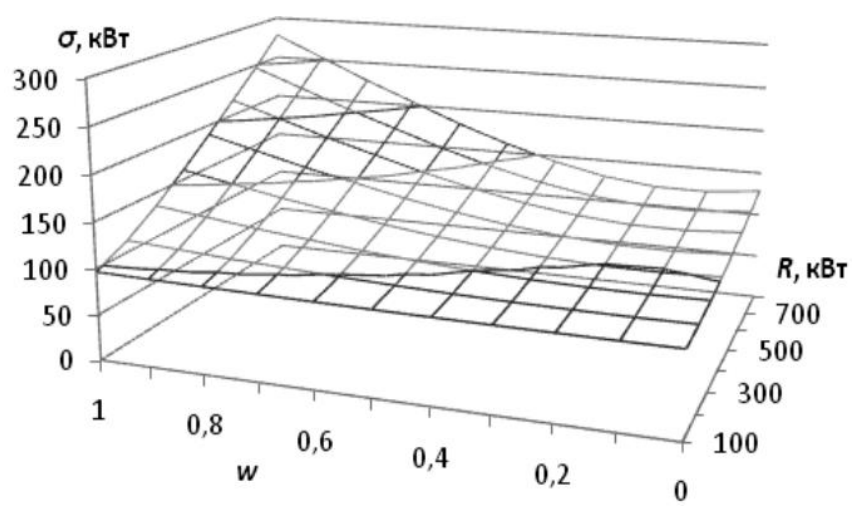

Рис. 2. Залежність СКВ від загальної потужності та складу ВДЕ (січень)

Fig. 2. Dependence of deviation on total capacity and composition of RES (January)

За результатами січня зазначимо, що мінімальна абсолютна дисперсія спостерігається при частці ВЕС $w=0,1$ (взимку роль сонячної енергії мінімальна). Відносна варіація мінімальна при частці ВEC в межах від 0,2 до 0,3 (оптимальна частка ВЕС трохи зростає при збільшені рівня впровадження ВДЕ, рис. 3б).

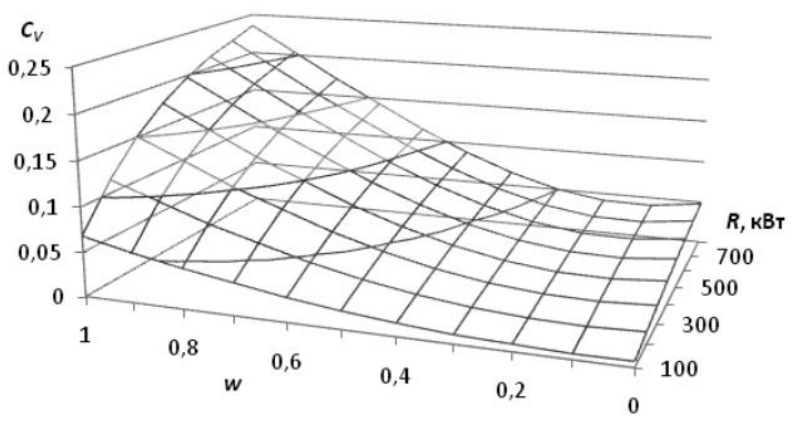

a)

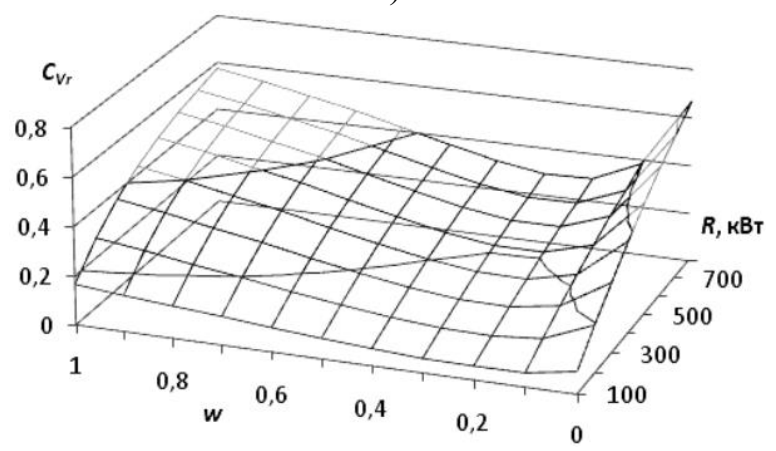

б)

Рис. 3. Залежність додаткової варіативності $C_{V}\left(\right.$ a) та $C_{V r}$ (б) від рівня та складу ВДЕ

Fig. 3. Dependence of additional variability of $C_{V}$ (a) and $C_{V r}$ (b) on level and composition of RES 
Оптимальність конфігурації ВДЕ в локальній енергосистемі визначатиметься критерієм, обраним при виборі проектних рішень [13]. 3 розглянутих співвідношень вітрової та сонячної складових генерування електроенергії можна визначити варіанти 3 мінімальною дисперсією генерації ВДЕ, або з мінімальним відношенням дисперсії до середньої генерованої потужності. При врахуванні мінливого характеру споживання в енергосистемі можна відокремити додаткову мінливість, спричинену заміною частини контрольованої (традиційної, мережевої) генерації на ВДЕ. В цьому випадку можлива деяка кореляція режимів споживання та генерації, тому результуюча варіативність залежатиме від споживача. Однак, як показують дослідження, зокрема наведені вище, поточні флуктуації споживання та генерації на коротких (до години) часових інтервалах практично незалежні, а коефіцієнти кореляції можуть приймати як позитивні, так і негативні значення $з$ малими (до 0,3 ) абсолютними величинами. Отже, характер додаткової варіативності внаслідок впливу ВДЕ визначатиметься переважно погодними факторами, властивими даному регіону та залежними від пори року.

Якщо в якості критерію обрано мінімізацію сукупної дисперсії або додаткової варіативності навантаження енергосистеми при впровадженні ВДЕ у складі вітрової та сонячної генерації, то оптимальним рішенням буде певна пропорція вітрової та сонячної складової за середньорічними чи сезонними погодними умовами (як правило, частка ВЕС має складати $10-40 \%$ сукупної номінальної потужності ВДЕ залежно від загальної частки ВДЕ). Такий розв'язок при наявності достатніх статистичних даних про погодні фактори знаходиться безпосередньо описаним вище шляхом.

В якості обмеження може бути вимога не перевищити певний рівень дисперсії. Тоді арбітражною зоною розв'язків буде крива горизонтального перетину поверхні відгуків (рис. 2, 3) на певній висоті. Однак природнішим виглядає обмеження не по дисперсії (чи СКВ), а по амплітуді випадкових відхилень (флуктуацій) від графіка навантаження. Якщо таке обмеження задано як максимально допустиме відхилення, то 3 урахуванням імовірнісної природи ВДЕ воно може виконуватися з певною вірогідністю. Відповідно до гіпотези про нормальний розподіл флуктуацій [11] теоретичні відхилення можуть досягати не- скінченність, але 3 нульовою імовірністю. На практиці такі відхилення обмежені. В розглянутих вище прикладах для типових споживачів зафіксовані дані (за винятком екстремальних викидів, кількість яких обмежено як $0,3 \%$ випадків) знаходились всередині діапазону $\left(Q_{1}-1,5 \cdot I Q R\right.$; $\left.Q_{3}+1,5 \cdot I Q R\right)$, де $Q_{1}$ та $Q_{3}-$ перший та третій квартилі розподілу; $I Q R$ - інтерквартильний розмах. В більшості прикладів розмах відхилень не перевищував $2,5 \sigma$. В межах цього діапазону розподіл можна вважати нормальним. Тоді обмеження по абсолютній величині відхилень $\left(p_{i j} \leq p_{0}\right)$ можна перевести в обмеження по величині СКВ:

$$
\sigma_{\max }=\arg \left\{\Phi\left(p_{0} / \sigma\right)=\gamma\right\},
$$

де $\Phi$ - інтеграл імовірності, $\gamma$ - довірча імовірність. На графіку СКВ (рис. 2) це обмеження матиме вигляд кривої в горизонтальній площині, область під проекцією якої на координатну площину $(w, R)$ містить допустимі розв'язки. Нехай рівняння цієї проекції: $R=\varphi(w)$, тоді оптимальним рішенням буде $w_{0}=\arg \left\{r^{\prime}(w)=0\right\}, \quad$ або розв'язок рівняння

$$
\begin{aligned}
r^{\prime}(w) & =\phi^{\prime}(w)\left[\left(k_{w}-k_{s}\right) w+k_{s}\right]+ \\
& +\phi(w)\left(k_{w}-k_{s}\right)=0,
\end{aligned}
$$

де $r(w)=\varphi(w)\left[k_{w} w+k_{s}(1-w)\right]$ відповідно до формули (2). В такій постановці задача оптимізації стає детермінованою.

Як приклад розглянемо того ж споживача, для якого середньорічне навантаження становить 800 кВт, СКВ відхилень від графіка навантаження (флуктуацій споживання) по сезонах року: 90, 54, 67, 88 (кВт), а розмах флуктуацій протягом року \pm 200 кВт. Нехай умови оптимізації: максимум ефективної потужності ВДЕ при обмеженнях на флуктуації навантаження 250 кВт протягом 90\% часу, тобто $P\left\{\left|p_{i j}-p_{i}\right| \leq p_{0}\right\} \geq 0,9$, де $p_{0}=250$ кВт. Тут $p_{0}$ становить понад $30 \%$ середньої річної потужності навантаження. 3 умови (4) випливає: $\Phi\left(p_{0} / \sigma\right) \geq 0,95$ (з урахуванням симетрії розподілу) і звідси отримаємо $\sigma_{\max }=150$ кВт. Для горизонтальних проекцій з рис. 2 отримаємо графічне зображення функцій $R=\varphi(w)$ (рис.4).

Аналогічно, знаючи $\varphi(w)$ та використовуючи (2), можна побудувати залежності $r(w)$. Криві на рис.4 відповідають певним (в даному випадку 
фактичним за січень 2016 р.) значенням продук-

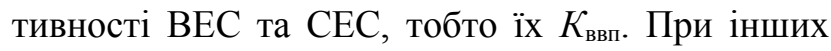
значеннях $k_{w}$ та $k_{s}$ розташування екстремумів кривих змінюватиметься (рис.5).

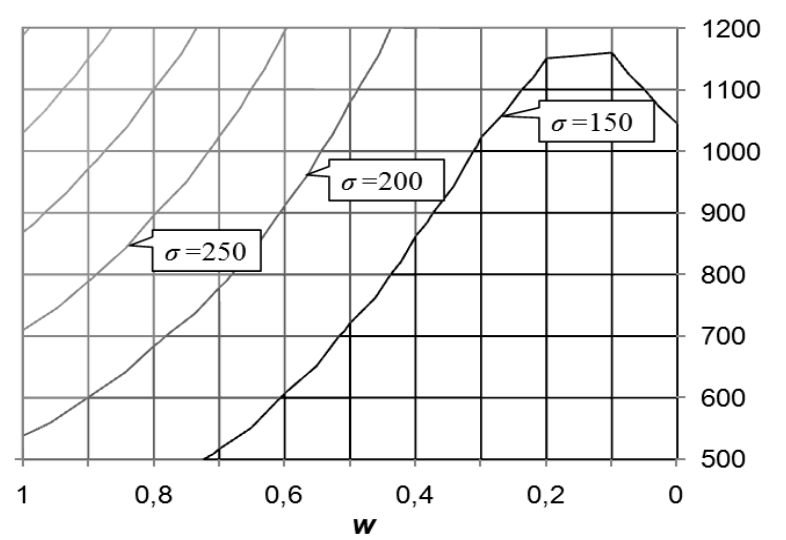

Рис. 4. Залежності $R=\varphi(w)$ при різних значеннях допустимої СКВ $\left(\sigma_{\max }\right)$

Fig. 4. Dependence $R=\varphi(w)$ at different values of the permissible deviation $\left(\sigma_{\max }\right)$

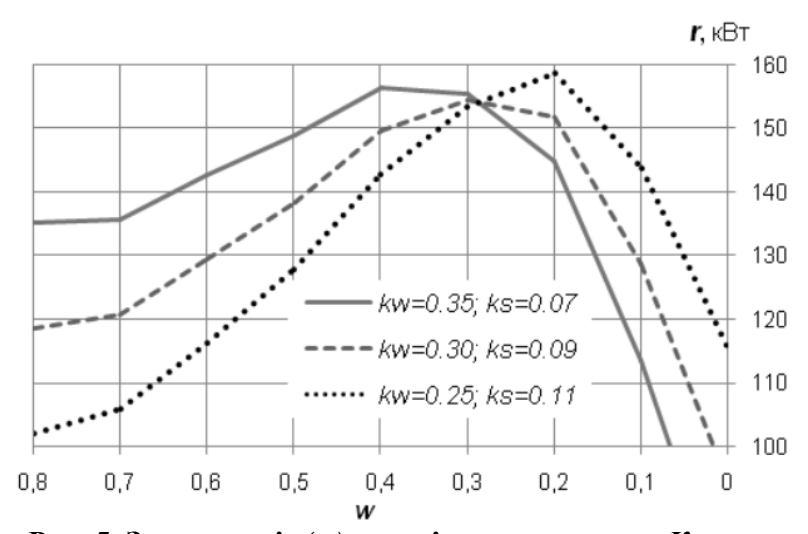

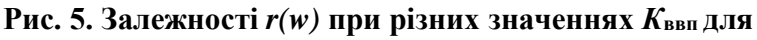
BEC Ta CEC

Fig. 5. Dependence $r(w)$ at different values of capacity factor for WPP and PV

Для даних січня (рис.2, 4) область, для якої $\sigma \leq 150$ кВт, обмежена кривою 3 максимумом $R=1150$ кВТ при частці ВЕС $w=0,12$. Максимум ефективної потужності ВДЕ досягається при частці ВЕС $w_{0}=0,2-0,4$; абсолютне значення зале-

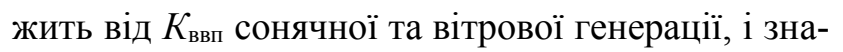
ходиться на рівні $r=155-160$ кВт для існуючих типів електроустановок. Для січня більш характерним $€$ перший варіант $K_{\text {ввп }} 3$ рис.5: $k_{w}=0,35$; $k_{s}=0,07$. Тоді перевага має надаватись вітровим установкам, приймаючи $w_{0}=0,4$. При загальній номінальній потужності ВДЕ 1150 кВТ це означає 460 кВт ВЕС та 690 кВт СЕС.

Перевіримо таким же чином умови липня. Область, де $\sigma \leq 150$ кВт, обмежена кривою 3 максимумом $R=1480$ кВт при частці $\mathrm{BEC} w=0,12$.

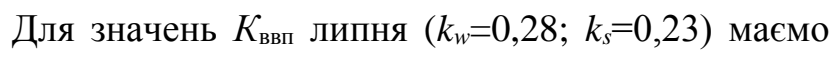
максимум $r=350$ кВт при частці ВЕС $w_{0}=0,2$. Тоді це означає 300 кВт ВЕС та 1180 кВт СЕС.

Для квітня $k_{w}=0,44 ; k_{s}=0,19$. Для $R=1100$ кВТ маємо $r=285$ кВт при $w_{0}=0,28$.

Для жовтня $k_{w}=0,5 ; k_{s}=0,12$. Для $R=1050$ кВт маємо $r=286$ кВт при $w_{0}=0,44$.

Такими є результати оптимізації для окремих місяців. Якщо треба розрахувати оптимальну конфігурацію для всього року, необхідно брати до уваги весь масив даних, оскільки довірчі межі для розкиду флуктуацій навантаження мають стосуватися всього року. При цьому розподіл флуктуацій протягом року може бути нерівномірним, а в окремі місяці їх частка перевищуватиме середньорічний довірчий діапазон. В даному прикладі умова $\Phi\left(p_{0} / \sigma\right) \geq 0,95$ була застосована до кожного місяця, інакше мало б бути попередньо обумовлено можливість сезонної зміни конфігурації системи, тобто часткове обмеження роботи ВДЕ при варіації погодних умов. Отже, в загальному випадку область допустимих значень $(w, R)$ буде обмежена найбільш жорсткими умовами. В даному прикладі це стосується внутрішньої області кривої $\sigma=150$ для січня (рис.4) на ділянці $(w \geq 0,2)$. Оптимум по критерію максимуму ефективної потужності ВДЕ знаходиться на обмежувальній кривій. Для інтервалу $(0<w<0,2)$ жорсткішими будуть обмеження жовтня, але цей інтервал не є оптимальним в кожному місяці (рис. 6).

Приведена оцінка не враховує питому вагу окремих місяців, які характеризуються різною ефективною потужністю ВДЕ. Коректніше було б представити повний набір річних даних шляхом складання частоти певних відхилень та визначення інтегральної функції їх розподілу. В цьому випадку осереднюються також значення $K_{\text {ввп. }}$

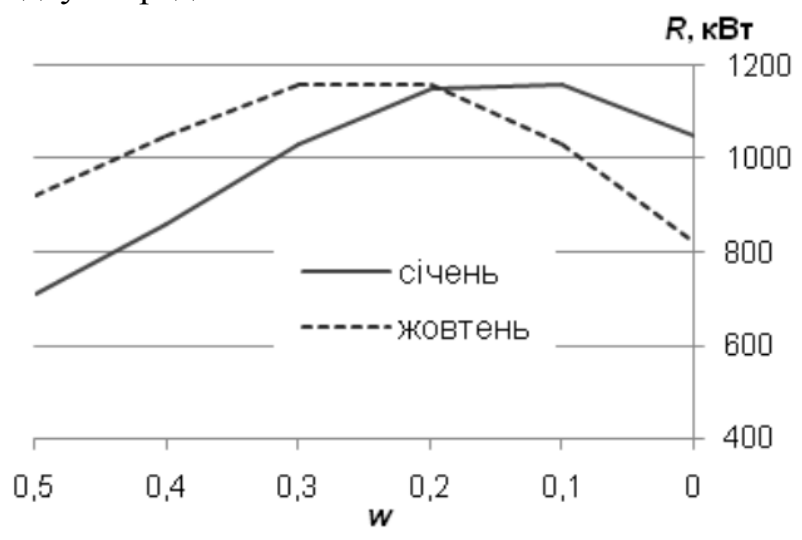

Рис. 6. Ізолінії $R$ для $\sigma=150$ кВт в різні місяці

Fig. 6. Isolines $\mathrm{R}$ for $\sigma=150 \mathrm{~kW}$ in different months 
Оцінка оптимальності виконувалася в припущенні, що графік навантажень побудовано за середньомісячними даними. Наскільки зміниться результат, якщо графік складатиметься з урахуванням прогнозу на кожну добу, причому прогноз стосуватиметься лише середньодобових значень? Для цього до середньомісячного добового ходу вносимо поправку на середньодобове значення розрахункової доби.

Максимальна допустима потужність ВДЕ при добовому прогнозуванні і при тих же обмеженнях: $R=1550$ кВт при $w_{0}=0,25$, а оптимальна 1450 кВт при $w_{0}=0,35$. При цьому максимум споживання ВДЕ рівний 361 кВТ, річний $K_{\text {ввп }}$ ВДЕ становитиме 0,25. Отже, наявність прогнозування споживання та генерації за добу (з забезпеченням середньодобового значення) дозволить на $40 \%$ збільшити використання енергії ВДЕ при збереженні обмежень на розкид відхилень від графіка навантаження. Рівень $K_{\text {ввп }}$ також дещо зросте за рахунок збільшення частки ВEC. Якщо ж потужність ВДЕ збережеться на тому ж рівні, то довірчий інтервал відхилень від графіка зменшиться 3250 КВт до 200 кВт, відповідно зменшиться потреба в компенсуючих потужностях.

Для перспективного моделювання можливих ситуацій потрібно встановити характер розподілу випадкових величин (метеофакторів і рівня споживання) та розрахувати параметри розподілу. Далі оптимізація виконується аналогічно, тільки замість відомого набору даних $p_{i j}$ використовується їх імітація та статистична обробка методом Монте-Карло.

Якщо умовою оптимізації є обмеження на розкид відхилень від осередненого графіка споживання і можна аналітично оцінити оптимальні співвідношення різних видів ВДЕ (вітру та Сонця) за статистичними даними, які не обов'язково $\epsilon$ синхронними; важливо оцінити параметри розподілу імовірності випадкових складових.

Якщо в якості обмеження виступає розмах відхилень $\left(p_{0}\right)$ або відповідне СКВ $\left(\sigma_{\max }\right)$, які пов'язані умовою (4): $\Phi\left(p_{0} / \sigma_{\max }\right)=\gamma$, то оцінку мінливості «чистого» навантаження можна здійснити за параметрами розподілу потужності ВДЕ. Нехай прогнозоване значення споживання, як осереднений добовий хід вважається відомим i $\epsilon$ заданим графіком навантаження, який враховує i осереднені значення ВДЕ. Тоді дисперсія наван- таження з урахуванням ВДЕ визначається як сума окремих складових:

$$
\begin{gathered}
\sigma_{p}^{2}=D\left(p_{i j}\right)=D\left(a_{i j}\right)+D\left(w_{i j}\right)+D\left(s_{i j}\right)+ \\
+2[\operatorname{cov}(a, w)+\operatorname{cov}(a, s)+\operatorname{cov}(w, s)] .
\end{gathered}
$$

Вважаючи випадкові величини незалежними, як зазначено вище, приймаємо їх коваріації рівними нулю. Виходячи 3 фізичних обмежень на розмах флуктуацій потужностей ВЕС та СЕC, вважаємо їх СКВ пропорційними номінальній потужності:

$$
\sigma_{w}=\alpha_{w} w R, \sigma_{s}=\alpha_{s} s R=\alpha_{s}(1-w) R .
$$

Тоді граничні обмеження флуктуацій матимуть вигляд:

$$
\begin{aligned}
\sigma_{p}^{2} & =\sigma_{\max }^{2}=\sigma_{a}^{2}+\sigma_{w}^{2}+\sigma_{s}^{2}=\sigma_{a}^{2}+ \\
& +R^{2}\left[\alpha_{w}^{2} w^{2}+\alpha_{s}^{2}(1-w)^{2}\right] .
\end{aligned}
$$

Оскільки дисперсія потужності споживача не залежить від рівня впровадження ВДЕ і вважається відомою, то умову щодо обмежень на потужність ВДЕ можна представити у вигляді:

$$
R \sqrt{\alpha_{w}^{2} w^{2}+\alpha_{s}^{2}(1-w)^{2}}=\sqrt{\sigma_{\max }^{2}-\sigma_{a}^{2}}=\text { const },
$$

а критерієм оптимізації максимум ефективної потужності $r(2)$. Шукаючи точку екстремуму $r$, як раціональної функції від $w$, отримаємо:

$$
w_{0}=\frac{\alpha_{s}^{2} k_{w}}{k_{s} \alpha_{w}^{2}+k_{w} \alpha_{s}^{2}} .
$$

До даного розв'язку входять нормовані імовірнісні параметри лише ВДЕ незалежно від споживача, які визначаються типом обладнання та потенціалом ВДЕ, притаманним даному регіону та порі року. При цьому вигляд функції щільності розподілу не враховується, важливі лише показники дисперсії, що є певним спрощенням задачі. Самі дисперсії розраховуються за статистичними даними, що охоплюють декілька років (до трьох).

Якщо означений критерій застосувати до розглянутих вище прикладів, отримаємо для річного обсягу даних $w_{0}=0,28$ (при значеннях коефіцієнтів $\left.k_{w}=0,40 ; k_{s}=0,15 ; \alpha_{w}=0,33 ; \alpha_{s}=0,13\right)$. Це досить близько до результатів, отриманих ретроспективним аналізом для різних споживачів; деякі відхилення можуть бути спричинені наявністю кореляції складових балансу, хоч і загалом незначної. Значення для окремих місяців можуть 
мати більші відмінності внаслідок імовірної кореляції на коротких часових інтервалах, проте річні значення досить стійкі, що важливо, адже проектна експлуатація має тривати роками.

Висновки. При масштабному впровадженні вітрової та сонячної генерації важливим $є$ питання забезпечення балансу потужностей та відповідного виробництва і споживання електроенергії. За рахунок комбінування потужностей ВЕС та CEC в певних пропорціях можливо зменшити випадкову складову генерації і тим самим уникнути значного небалансу. Оптимальне співвідношення вітрової та сонячної генерації залежить від кліматичних умов та енергетичних характеристик, зокрема коефіцієнта використання встановленої потужності. Крім того, оптимальність визначатиметься обраним критерієм, який може стосуватися як варіативності, так і сукупної продуктивності, економічної ефективності, тощо. Важливим фактором є також можливість прогнозування поточного споживання електроенергії та інтенсивності вітрової і сонячної енергії. Так, наявність прогнозу хоча б середньодобового рівня потужностей дозволяє в півтора рази збільшити обсяг впровадженої відновлюваної енергії при тому ж рівні стабільності енергопостачання.

1. Лежнюк П., Комар В., Собчук, Д. Оцінювання впливу джерел відновлюваної енергії на забезпечення балансової надійності в електричній мережі. Вісник Вінницького політехнічного інституту. 2013. 6. С. 45-47. URL: https://visnyk.vntu.edu.ua/index.php/visnyk/article/view/1005.

2. Bernal-Agustín J.L., Dufo-Lopez R. Simulation and optimization of stand-alone hybrid renewable energy systems. Renewable and Sustainable Energy Reviews. 2009. Vol. 13. No. 8. Pp. 2111-2118. doi:10.1016/j.rser.2009.01.010.

3. Bhandari B. et al. Optimization of hybrid renewable energy power systems: A review. International journal of precision engineering and manufacturing-green technology. 2015. Vol. 2. No. 1. Pp. 99-112.

4. Wang X., Palazoglu A., El-Farra N. Operational optimization and demand response of hybrid renewable energy systems. Applied Energy. 2015. Vol. 143. Pp. 324-335. doi:10.1016/j.apenergy.2015.01.004

5. Siddaiah $R$., Saini $R$. A review on planning, configurations, modeling and optimization techniques of hybrid renewable energy systems for off grid applications. Renewable and Sustainable Energy Reviews. 2016. Vol. 58. Pp. 376-396. doi:10.1016/j.rser.2015.12.281

6. Bahramara S., Moghaddam M., Haghifam M. Optimal planning of hybrid renewable energy systems using HOMER: A review. Renewable and Sustainable Energy Reviews. 2016. Vol. 62. Pp. 609-620. doi:10.1016/j.rser.2016.05.039.

7. Павловський В.В., Лук'яненко Л.М., Гончаренко І.С., Захаров А.М. Обмеження потужності відновлюваних джерел енергії за умовами приєднання до електричної мережі. Праці ІЕД НАНУ. 2016. вип. 43. С. 18-23.

8. Кузнєцов М.П., Ужейко С.О. Імовірнісні аспекти використання відновлюваних джерел енергії в зоні відчуження Чорнобильської АЕС. Відновлювана енергетика. 2016. №3. C. 6-12.

9. Кузнєцов М.П. Вплив вітрової енергетики на статичну стійкість енергосистеми. Відновлювана енергетика. 2015. №3. C. 5-9.

10. Лисенко О.В. Оцінка випадкових властивостей рівнів споживання електроенергії. Відновлювана енергетика. 2018. № 1. С. 26-35.

11. Кузнєцов М.П. Побудова математичної моделі режиму споживання електроенергії. Відновлювана енергетика. 2017. № 4. C. 33-42.

12. Olsson M., Perninge M., Soder L. Modeling real-time balancing power demands in wind power systems using stochastic differential equations. Electric Power Systems Research. 2010. № 80. Pp. 966-974.

13. Кузнєиов М.П., Лисенко О.В., Мельник О.А. Особливості стохастичної оптимізації гібридних енергосистем на базі ВДЕ. Відновлювана енергетика. 2018. № 2. С. 6-15.

\section{К ОПТИМАЛЬНОМУ КОМБИНИРОВАНИЮ ВЕТРОВОЙ И СОЛНЕЧНОЙ ЭЛЕКТРОСТАНЦИЙ}

М.П. Кузнецов ${ }^{1}$, доктор технических наук, О.В. Лисенко ${ }^{2}$, кандидат технических наук, А.А. Мельник ${ }^{3}$, аспирант.

${ }^{1}$ Институт возобновляемой энергетики НАН Украины 02094 г. Киев, ул. Г.Хоткевича, 20А.

${ }^{2}$ Таврический государственный агротехнологический университет

72310 г.Мелитополь, ул. Б.Хмельницкого, 18.

${ }^{3}$ Национальный технический университет Украины «Киевский политехнический институт им. Игоря Сикорского». 03056, г. Киев, пр-т Победы, 37.

Целью данной работы является определение оптимального соотночения различных источников возобновляемой энергии в гибридных энергосистемах, основываясь на оценках случайной составляющей мощностей генерачии и потребления электроэнергии. Для этого рассматриваются краткосрочные колебания мощности, вызванные природными изменениями солнечной и ветровой энергии в диапазоне менее часа. Такие изменения влияют на возможности регулирования частоты и напряжения, а также устойчивости систем электроснабжения. Предметом исследования является пропориия ветровой и солнечной генерации, а также ее общий уровень в потреблении электроэнергии, а предметом оптимизачии - вариативность совокупной генерируемой мошности. Особенностью работы является синхронное сопоставлении уровней генерачии энергии и ее потребления различными локальными потребителями. Методы исследования - математическая модель комбинации случайных процессов и непосредственное использование статистических данных в качестве экспериментальных. В качестве метода оптимизачии избрано построение поверхности отклика, что обеспечивает визуализацию результатов при удовлетворительной точности. При необходимости результат уточняется методом дихотомии. Результать исследования сравниваются по уровню влияния погодных 
факторов, для чего рассматриваются данные различных времен года. Полученные зависимости позволяют также оценить влияние энергетической эффективности ветровой и солнечной энергетики как технологического фактора. Существенным результатом является оценка влияния точности прогнозирования мощностей генерации и потребления на энергетический баланс при составлении графиков работы энергосистемы - так, наличие суточного прогноза позволяет в полтора раза увеличить мощность ВИЭ при сохранении уровня вариативности. Установлено наличие оптимальных соотнотений мощңности ВЭС и СЭС, при которых минимизируется общая вариативность энергобаланса. В условиях Украины это составляет примерно треть номинальной мощности ВИЭ за счет ВЭС и две трети СЭС, однако результаты существенно зависят от сезона. Предложень критерии оптимальности, учитывающие случайную природу исследуемых процессов, что дает возможность вероятностной оценки результатов. Библ. 13, puc. 6.

Ключевые слова: возобновляемые источники энергии, солнечная электростанция, ветровая электростанция, энергобаланс, случайный процесс, оптимизациия.

\section{REFERENCES}

1. Lezhniuk, P., Komar, V. i Sobchuk, D. Otsiniuvannia vplyvu dzherel vidnovliuvanoi enerhii na zabezpechennia balansovoi nadiinosti v elektrychnii merezhi. [Assessment of the impact of renewable energy sources on the reliability of the electrical network]. Visnyk of Vinnytsia Polytechnical Institute. 2013. No. 6 Pp. 45-47. Retrived from https://visnyk.vntu.edu.ua/ index.php/visnyk/article/view/1005. [in Ukrainian].

2. Bernal-Agustín J.L., Dufo-Lopez R. Simulation and optimization of stand-alone hybrid renewable energy systems. Renewable and Sustainable Energy Reviews. 2009. Vol. 13. No. 8. Pp. 2111-2118. doi:10.1016/j.rser.2009.01.010. [in English].

3. Bhandari B. et al. Optimization of hybrid renewable energy power systems: A review. International journal of precision engineering and manufacturing-green technology. 2015. Vol. 2. No. 1. Pp. 99-112. [in English].

4. Wang X., Palazoglu A., El-Farra N. Operational optimization and demand response of hybrid renewable energy systems. Applied Energy. 2015. Vol. 143. Pp. 324-335. doi:10.1016/j.apenergy.2015.01.004 [in English].

5. Siddaiah R., Saini $R$. A review on planning, configurations, modeling and optimization techniques of hybrid renewable energy systems for off grid applications. Renewable and Sustainable Energy Reviews. 2016. Vol. 58. Pp. 376-396. doi:10.1016/j.rser.2015.12.281 [in English].

6. Bahramara S., Moghaddam M., Haghifam M. Optimal planning of hybrid renewable energy systems using HOMER: A review. Renewable and Sustainable Energy Reviews. 2016. vol. 62. Pp. 609-620. doi:10.1016/j.rser.2016.05.039. [in English].

7. Pavlovskyi V.V., Lukianenko L.M., Goncharenko I.S., Zaharov A.M. Obmezhennya potuzhnosti vidnovlyuvanykh dzherel enerhiyi za umovamy pryyednannya do elektrychnoyi merezhi. [Limitation of res power under the terms of connection to electric network]. Works of the Institute of Electrodynamics of the National Academy of Sciences of Ukraine. 2016. No. 43. Pp.18-23. [in Ukrainian].

8. Kuznietsov M., Uzheyko S. Imovirni aspekty vykorystannya vidnovlyuvanykh dzherel enerhiyi $\mathrm{v}$ zoni vidchuttya Chornobylskoyi AES. [Probabilistic aspects of renewable energy using in the Chernobyl zone]. Vidnovluvana Energetika. 2016. No. 3(46). Pp. 6-12. Retrived from http://ve.org.ua/index.php/journal/article/view/128[in Ukrainian]

9. Kuznietsov M.P. Vplyv vitrovoi enerhetyky na statychnu stiikist enerhosystemy [Influence of wind energy on the static stability of the grid]. Vidnovliuvana enerhetyka. 2015. No.3. Pp. 5-9 [in Ukrainian].

10. Lysenko, $O$. Otsinka vypadkovykh vlastyvostei rivniv spozhyvannia elektroenerhii. [Estimation of random properties of electricity consumptionlevels]. Vidnovluvana Energetika. 2018. No. 1(52). Pp.26-35. Retrieved from http://ve.org.ua/index.php/journal/article/view/8 [in Ukrainian].

11. Kuznietsov M. Pobudova matematychnoi modeli rezhymu spozhyvannia elektroenerhii. [Construction of a mathematical model of electricity consumption mode]. Vidnovluvana Energetika. 2017. No. 4(51). Pp. 33-42. Retrieved from http://ve.org.ua/index.php/journal/article/view/19 [in Ukrainian].

12. Olsson M., Perninge M., Soder L. Modeling real-time balancing power demands in wind power systems using stochastic differential equations. Electric Power Systems Research. 2010. No. 80. Pp. 966-974.

https://doi.org/10.1016/j.epsr.2010.01.004. [in English].

13. Kuznietsov M.P., Lysenko O.V., Melnyk O.A. Osoblyvosti stokhastychnoi optymizatsii hibrydnykh enerhosystem na bazi VDE. [Features of stochastic optimization for hybrid power systems with the renewable sources]. Vidnovluvana Energetika. 2018. No.2. Pp. 6-15. [in Ukrainian]. 